\begin{tabular}{|c|cc|}
\hline $\begin{array}{l}\text { Eurasian Academy of Sciences } \\
\text { Social Science Journal (Internatio/ Refereed \& Indexed) }\end{array}$ & Eurasian Academy of Sciences Social Sciences Journal \\
\hline \multicolumn{4}{|c|}{ Published Online May 2015 (http://socialsciences.eurasianacademy.org) } \\
http://doi.org/10.17740/eas.soc.2015-V3-05
\end{tabular}

\title{
Social Networks And Social Media: A Survey On University Students
}

Mustafa BOZ*, Selda UCA ÖZER**

Çanakkale Onsekiz Mart Üniversitesi, Turizm Fakültesi*, Trakya Üniversitesi, İIBF**

E-mail: m.b.istanbul@gmail.com*, suca5@hotmail.com**

Received : 27 February 2015; Published : 04 May 2015

Copyright (C) 2015 Mustafa BOZ, Selda UCA ÖZER. This is an open access article distributed under the Eurasian Academy of Sciences License, which permits unrestricted use, distribution, and reproduction in any medium, provided the original work is properly cited.

\begin{abstract}
Nowdays, Social media has almost become part of our daily lives. This study consists of two main parts: In the first part, in the light of literature, the concept, properties, usage areas and growth of social media are examined. In the second part of the study, a survey is realised among the students of Canakkale Onsekiz Mart University, and it is tried to determine their usage habits, usage purposes of social media and perceptions about social media. A face to face interview method was used in this study. In general, the reliability of the questionnaire was analyzed. In the statistical evaluation of the results of the survey, frequency distribution was utilized, in the Likert-scale questions, factor analyzes were conducted, and significant differences between means were analyzed by independent-samples t-tests, One- way ANOVA tests. Primary findings can be summarized: Almost, all students use internet and visit social media sites. Two-thirds of them use internet every day. Facebook is the most visited social media site. Previous reasons of the students to use social media are music, video, and photography share and instant case transmission. Students search carefully commends and recommendations written in social media sites before deciding to buy a product and brand. As a result, it can be stated that today, social media is not means used only by individuals or groups. At the same time, it has become the most important marketing tool of companies and institutions.
\end{abstract}

Keywords: Social media, Web 2.0, New media, Internet, Marketing

JEL Codes: M3, O3

\section{Sosyal Ağlar Ve Sosyal Medya: Üniversite Öğrencileri Üzerine Bir Araştırma}

\section{ÖZET}

Günümüzde, sosyal ağlar ve sosyal medya neredeyse günlük yaşamımızın bir parçası haline gelmiş bulunmaktadır. Çalışma iki ana bölümden oluşmaktadır. Birinci bölümde, alan yazın taranarak sosyal medya kavramı, sosyal medya araçları, özellikleri, kullanım alanları ve amaçları ile gelişmesi incelenmiştir. Çalışmanın ikinci bölümünde, Çanakkale Onsekiz Mart Üniversitesi öğrencileri ile alan çalışması yapılarak, sosyal medya kullanım alışkanlıkları, sosyal medyayı kullanım amaçları ve sosyal medya konusundaki algıları belirlenmeye çalışılmıştır. Çalışmada yüz yüze anket yöntemi kullanılmıştır. Anketin genel olarak 
güvenilirlik analizi yapılmıştır. Anket sonuçlarının istatistiksel olarak değerlendirilmesinde, frekans dağılımlarından yararlanmanın yanı sıra, likert ölçekli sorularda faktör analizleri yapılmış, ortalamalar arası anlamlı farklılıklar bağımsız iki grup arası farkların testi, varyans analizi (ANOVA) testleriyle ayrıca araştırılmıştır. Başlıca bulgular şu şekilde sıralanabilir: Öğrencilerin tamanına yakını internet kullanmakta ve sosyal medya sitelerini ziyaret etmektedirler. Üçte ikisi hergün internete girmektedir. En sık kullanılan sosyal medya sitesi Facebooktur. Öğrencilerin sosyal medya sitelerini öncelikli kullanım amacının müzik, video ve fotoğraf paylaşımı yapmak ve anlık durum iletimi fonksiyonlarını kullanmak olduğu görülmektedir. Öğrencilerin ürün ve marka satın alma kararını vermeden önce sosyal medya sitelerindeki yorum ve tavsiyeleri dikkate aldıkları anlaşılmaktadır. Sonuç olarak; günümüzde sosyal medya, sadece kişi ve grupların kullandığı bir araç değildir. Aynı zamanda şirketlerin ve kurumların en önemli pazarlama aracı haline gelmiş bulunmaktadır.

Anahtar Kelimeler: Sosyal medya, Web 2.0, Yeni medya, Internet, Pazarlama

\section{GIRIŞ}

Genel tanımıyla, sosyal medya oldukça yüksek erişilebilir ve ölçeklenebilir yayıncılık teknikleri kullanılarak, sosyal etkileşim yoluyla yayılması için tasarlanmış medyadır. Sosyal medyanın gelişmesi, internetin en büyük ve en son safhasıdır. Sosyal medya hareketi ilişkiler etrafında inşa edilmiştir. Sosyal medya siteleri, sanal ortamda insanlar arasındaki iletişimi teşvik etmek üzere bulunmaktadırlar. Bu siteleri kullanan insanlar, sadece tek yönlü iletişim değil, diğerleriyle etkileşim içinde de bulunmak istemektedirler. YouTube, Twitter, Facebook, LinkedIn, MySpace, Second Life, blogs, ve wikiler, sosyal medya platformlarından sadece bazılarıdır. Hatırlanması gereken en önemli şey, sosyal medyanın karşılıklı ilişki oluşturmak ve geliştirmek üzerine kurulduğudur.

Günümüzde, Sosyal medya hızla büyümekte ve hergün yön değiştirmektedir. Yakın gelecekte de büyümeye ve gelişmeye devam edecektir. Twitter, Facebook, Flickr, Instagram ve Bloglar gibi sosyal medya araçları fikirlerin, bilginin, geleneksel medyadan çok daha hızlı ve çok daha geniş bir alana yayılmasını ve yaratılmasını kolaylaştırmış bulunmaktadır. Günümüzde, sosyal medya - sosyal ağlar veya diğer isimlendirilmesiyle yeni medya neredeyse günlük yaşamımızın bir parçası haline gelmiş bulunmaktadır.

Sosyal medya original olarak farklı konularda, insanların görüşlerini ve düşüncelerini öğrenmek, belirli içerikleri, bağlantıları, fotoğrafları, videoları, bilgiyi ve bunun gibi şeyleri diğer üyelerle paylaşmaları için dizayn edilmiştir. Ancak sonraları, ulaşılması güç, daha geniş potansiyel müşteri kitlesini ve niş pazarları hedefleyen birçok işletme tarafından ürünlerini ve hizmetlerini tutundurmak için pazarlama aracı olarak kullanılmaya başlanmıştır. Günümüzde; kişisel kullanım yanında sosyal medya etkin pazarlama ve satış stratejileri ve uygulamaları için yeni bir araç haline gelmiş bulunmaktadır. Sosyal medya sitelerine katılan insanların sayısının hızla artması, sosyal medya pazarlamasına büyüyen oranda yatırım yapılmasına yol açmaktadır.

\section{LITERATÜR TARAMASI}

\subsection{Sosyal Medya Kavramı}

Sosyal medya ve sosyal ağların farklı tanımları bulunmaktadır. Örneğin Weber (2009) "sosyal ağ ortak ilgi alanları olan insanların düşüncelerini, yorumlarını ve fikirlerini paylaşmak için bir araya geldikleri çevrim içi yerdir" olarak tanımlamaktadır. Wikipedia'da (2011) sosyal medya "sosyal etkileşim için son derece erişilebilir ve ölçeklenebilir iletişim tekniklerini 
kullanan medya" olarak tanımlanmaktadır. Grenfield'e (2011) göre "Sosyal medya insanların katk1 vermesine izin veren bir dizi web sitesinin ortak terimidir. Örneğin YouTube, bir sosyal medya kanalıdır. Bloglar bir sosyal medya kanalıdır".

Sosyal medyada iletişim "sosyal ağlar" kullanılarak sağlanmaktadır. Bu siteler insan gruplarını bir araya getirerek iletişim kurmalarını sağlarlar. İnsanların çevrimdışı (sosyal) bir çevrede sahip olduğu gibi (örneğin bir kurumun, derneğin veya özel ilgi grubunun parçası olması gibi) çevrimiçi bir çevrede (sanal bir ortamda) davranışlarını tekrarlarlar. Çevrimiçi, çevre ağlara son derece uyumludur. Mekan ve zaman sınırlaması yoktur. Herkes her yerden, her zaman katılabilir (Tourism Queensland, 2011).

Boyd and Ellison (2007) sosyal ağı, bireylere (1) belirli bir sistem içinde kamuya açık veya yarı açık profil oluşturmaya, (2) kendileriyle bir bağlantıyı paylaşan diğer kullanıcıların listesini açıkça belirtmeye ve (3) sistem içindeki diğer kişiler tarafindan bağlantı listelerinin görülebilmesine ve her iki yöne hareket ettirilebilmesine izin veren web tabanlı hizmetler olarak tanımlamaktadır. Sosyal ağlar ortak ilgi veya çıkar alanları olan insanların benzer ilgi alanları olan insanlarla bir araya geldiği, kendilerini ifade ettikleri yerlerdir (Weber, 2009:5).

Sosyal medya geleneksel medya monologlarını, sosyal medya diyaloglarına dönüştürmek ve yaymak için web tabanlı teknolojileri kullanır. Sosyal medya bilginin ve haberin demokratikleşmesini destekler ve insanları hoşnut tüketicilerden hoşnut üreticilere dönüştürür (wikipedia, 2011). Sosyal medya hareketi için anlamamız gereken ilk şey, onun ilişkiler etrafında inşa edildiğidir. Sosyal medya siteleri insanlar arasındaki iletişimin gelişmesine yardımcı olmak için vardır. Bu siteleri kullanan insanlar, sadece tek yönlü iletişim deneyimi değil, diğerleri ile etkileşime geçmek istemektedir (Rothamel, 2007).

\subsection{Sosyal Medya Mecraları}

Sosyal web bireyler veya işletmeler tarafından web de yaratılmış ücretsiz yeni bir medya dünyasıdır. Her dakika değilse bile, her saat kamuoyu görüşünü değiştirme kapasitesine sahip bu yeni stratejiler yüzbinlerce sosyal medya hizmetini ve araçlarını içermektedir. Sosyal medya araçları aşağıdaki gibi sınıflandırılabilir ( Lips, 2011; Weber, 2009).

- Bloglar - Wordpress, Blogger, Typepad

- İçerik Paylaşımı - YouTube, Flickr, Photobucket, Instagram

- Sosyal Ağlar - MySpace, Facebook, Gather, BlackPlanet, Eons, LinkedIn

- Profesyonel Ağlar - LinkedIn, ecademy, xing

- Mikroblog ve bulunma - Plazes, Twitter, Jaiku

- Demokratik içerik - Digg

- Tercih Paylaşımı - Last FM, Wakoopa

- Markalı web alanları - Amazon, Netfl ix, eBay

- Girişim siteleri - IBM, Best Buy, Cisco, Oracle

- Arama motorları - Google, Yahoo!, Ask ve Live, Yandex vb.

\subsection{Sosyal Medyanın Özellikleri}

Geleneksel gazeteler, dergiler, radyo ve televizyon kanalları gibi kontrol altındaki medya yayıncı veya kurumlarda iletişim büyük bir oranda tek yönlüdür. Profesyonel gazetecilerin yazdığı ve araştırdığı hikayeler yayına hazırlanır ve kamuoyuna sunulur. Bununla beraber, bloglar gibi sosyal medyada herkese yayın yapmak ve çevrimiçi çoklu paylaşımlara katkıda bulunmaları için izin verilir. Çünkü, bazen "vatandaş gazeteciler" ve hatta "vatandaş 
pazarlamacılar" olarak adlandırılan blogerların hiçbir editoryal kısıtlamaları yoktur ve tüm ağa erişebilirler. Mesajları ürün veya şirketlerin şöhretine olumlu katkı sağlayabilir veya zarar verebilir (Weber, 2009:5).

Lancaster Üniversitesi İleri Araştırmalar Enstitüsü'nden Michael Hulme'un araştırma raporuna göre, araştırmaya katılanların \%95'i reklamlara güvenmediklerini, \%10'dan azı $(\% 8)$ şirketlerin kendi haklarında söylediklerine inandıklarını belirtmişlerdir. Yarıdan fazlası (\%58) "şirketler, ürünün veya hizmetin benim için doğru olup olmadığına bakmadan, sadece ürünlerini ve hizmetlerini bana satmakla ilgilidirler", ifadesini paylaştıklarını belirtmişlerdir. Belki de en önemlisi olarak, araştırmaya katılanların sadece \%17'si şirketlerin kendilerinin ne söylediğini ciddiye aldığına inandığını ifade etmişlerdir (Robles, 2010).

Sosyal medya insanların alışveriş davranışlarını da etkilemektedir. Digital Influence Group'un raporuna göre, tüketici yorumlarında insanların \%91'inin, sosyal medyanın alışveriş kararlarına yardımcı olduğunu, \%87'si eleştiri yorumlarında bir arkadaşlarının tavsiyelerine güvendiğini söylemişlerdir. Alışveriş kararları için benzer fikirlere reklamlardan, üç kat daha fazla güven duyulmaktadır. 1 ağızdan ağza söylesi 200 televizyon reklamının sahip olduğu etkiye sahiptir (Tay, 2011).

50 ülkede 25.000 den fazla internet tüketicisi ile yapılan, Nielsen Global Çevrimiçi Tüketici Araştırmasına göre, tanıdıkların kişisel tavsiyeleri veya çevrimiçi tüketicilerin fikirlerini ifade ettikleri mesajlar, reklamın en güvenilir biçimidir. Araştırmaya katılan tüketicilerin \%90'1 tanıdıkları insanların tavsiyelerine güvendiklerini belirtirken, \%70'i çevrimiçi tüketicilerin fikirlerini ifade ettikleri mesajlara güvendiklerini belirtmişlerdir (Nielsen Company, 2009).

Sosyal medyanın özellikleri aşağıdaki gibi sınıflandırılabilir.

1. Katılım: Sosyal medya, iletişim kurulan kişilerin geribildirimde bulunmasını ve gerekli katkılar göstermesini kolaylaştırır. Medya ile izleyicisi arasındaki çizgiyi silikleştirerek, patronajı kullananın hizmetine verir.

2. Açıklık: İçeriğe erişim ve kullanımda mümkün olduğu kadar engelleri bertaraf eder. Kullanımı son derece açık ve kolaylaştırılmıştır.

3. Karşılıklı Konuşma: Geleneksel medya daha çok tek yönlü bir iletişim içermektedir. Klasik kitle iletişim araçlarında geribildirim zordur ve zaman alır. Buna karşılık sosyal medya bireylere, çift yönlü iletişim, rahat ve zamanında geribildirim sunar.

4. Topluluk: Sosyal medya toplulukların ilgili konu veya kişiler üzerinde hızla oluşmasına ve buna bağlı olarak etkin bir şekilde iletişim kurulmasına izin verir.

5. Bağlantısallık: Birçok sosyal medya bağlantısaldır. Kullanıcı kolaylığı, reklam veya herhangi bir gerekçeden dolayı diğer sitelere, kaynaklara ve kişilere link verir.

\subsection{Sosyal Medya İstatistikleri}

Dünya üzerinde internet kullanımı giderek yaygınlaşmaktadır. 2014 yılında yapılan güncel araştırmalarda belirlenen rakamlara göre tüm dünyada ve Türkiye' de internet ve sosyal medya kullanıcı istatistikleri aşağıdaki gibidir (dijitalajanslar.com, 2014; We are social, 2014).

- Dünya üzerinde 2.5 milyar insan internet kullanmaktadır. Bu kullanıcıların 1.8 milyarının sosyal medya ağlarında hesabı vardır. Türkiye'de 35 milyonun üzerinde internet kullanıcısı bulunmaktadır. Türkiye'de internet kullanım oranı, tüm nüfusa oranla \%45’tir.

- Kıtalar arası bazda internet kullanımında Kuzey Amerika \%81’lik bir oranla başı çekmektedir. İnternet kullanımının en az yaygın olduğu bölge ise Güney Asya’dır (\%12).

- Yalnızca 2013'te, 135 milyon insan daha sosyal ağlarda hesap oluşturmuş bulunmaktadır. 
- Sosyal medya aktif kullanıcı sayıları her geçen yıl artmaktadır. Facebook, 1,184 milyarlık güncel aktif kullanıcı sayısı ile sosyal ağlar arasındaki liderliğini korumaktadır.

- Aktif kullanıcı sayılarına göre en popüler ilk 10 sosyal medya platformu ise şöyle siralanmaktadir: 1. Facebook (1,184 milyar), 2. QQ (Tencent) (816 milyon), 3. Qzone (632 milyon), 4. Whatsapp (400 milyon), 5. Google+ (300 milyon), 6. Wechat (272 milyon), 7. LinkedIn (259 milyon), 8. Twitter (232 milyon), 9. Tumblr (230 milyon), 10. Tencent Weibo (220 milyon)

- Mobil penetrasyonun en güçlü olduğu bölgeler, Avrupa, Güney Amerika ve Ortadoğu'dur.

- İngiltere, \%87'lik bir oranla, internetin en yaygın kullanıldı ̆̆ ülke olarak lider konumdadır. İngiltere'yi Kanada (\%86), Almanya (\%84), Güney Kore (\%84) ve Fransa (\%83) izlemektedir. Kalabalık nüfusu ile Çin, internet kullanımında \%42'lik bir oranla gelişmiş ülkelerin gerisinde kalmaktadır.

- Kişisel bilgisayarlar üzerinden internette en çok vakit geçiren ülke, günlük ortalama 6.1 saat ile Brezilya'dır.

- Mobil cihazlar aracılığıyla internete bağlantı kurmayı en çok seven ülkeler Güney Amerika ve Arap ülkeleri'dir.

- Türkiye’de günde ortalama 4.9 saatimizi kişisel bilgisayarlar üzerinden, 1.9 saatimizi mobil cihazlar aracılığıyla internette harcamaktayız. Günde ortalama 2 saat 32 dakikamızı sosyal medyada geçirmekteyiz.

- Amerika, Fransa, Almanya, Kanada, Brezilya, İtalya ve Japonya gibi gelişmiş ülkelerde en çok tercih edilen iki sosyal ağ, Facebook ve Twitter'dır .

- Türkiye'de en çok kullanılan sosyal medya platformu olan Facebook’u (\%93), sırayla Twitter (\%72), Google+ (\%70) ve LinkedIn (\%33) takip etmektedir.

- Amerika'da internet kullanıcılarının \%85'inin Facebook'ta, \%46'sının ise Twitter'da hesabı bulunmaktadır. Amerikalıların sosyal ağlar arasında en çok tercih ettikleri diğer siteler ise LinkedIn ve Google+'tır.

- Araştırma sonuçlarındaki en ilginç noktalardan biri, lokal sosyal ağların yükselişe geçmiş olmasıdır. Facebook, Twitter, Google + ve Youtube gibi global sosyal ağlar dışında; Rusya, Çin ve Hindistan gibi büyük nüfuslu ülkelerde tercih edilen lokal / bölgesel sosyal ağlar da dünya çapında sosyal ağ kullanım oranlarında hatırı sayılır bir değer değişikliği yaratmaktadir.

- Rusya'da 2006'da kurulan Vkontakte Rusya, Belarus ve Ukrayna'da kısa zamanda en popüler sosyal ağ konumuna gelmiş bulunmaktadır. Rusya'da internet kullanıcılarının \%75'inin Vkontakte hesabı bulunmaktadır. Vkontakte'yi \%69'luk kullanım oranıyla

Odnoklassniki izlemektedir. Rusya'da Facebook hesabı olan internet kullanıcılarının oranı ise \%68 seviyesindedir.

- Benzer bir durum Çin'de de geçerlidir. 2009'da kurulan mikroblog ve sosyal paylaşım sitesi Sina Weibo Çinliler tarafından en çok kullanılan sosyal ăg (\%83) konumundadır.

- 2013'ün son çeyrek verilerine göre 623.3 milyon aktif kullanıcı sayısı ile Çin'in en büyük sosyal ağlarından Qzone ve Çin'de Youtube'dan daha fazla tercih edilen video arama motoru Youku (\%56) da yerel sosyal ağların gücünün azımsanmayacak boyutlara ulaştığını göstermektedir. 
- Yine Çin merkezli bir sosyal ağ olan Tencent -yaygın kullanılan adıyla QQ- dünyanın en çok kullanılan sosyal ağları listesinde ikinci sırada bulunmaktadır.

- Hindistan'da da Facebook (\%94) ve Twitter'1n (\%67) popülaritesine ek olarak, en sik kullanılan sosyal ağlardan biri, 2004 yılında Google bünyesinde kurulan Orkut'tur (\%51).

Genel olarak bakıldığında, Ocak 2014 verileri mobil internet erişimindeki büyük artışlara dikkat çekerken; sosyal ağ kullanımında bölgesel parametrelerin de aynı zamanda önemli bir belirleyici olduğunun altını çizmektedir. Pew Internet ve Amerikan Life Project tarafindan 2009 yılında 2,253 kişi ile yapılan bir çalışmanın sonuçlarına göre Twitter ve benzer hizmetlerin kullanımı gençler arasında daha popülerdir. Bu oranlar; 18-24 yaş arasında \%37, 25-34 yaş arasında \%31, 35-44 yaş arasında \%19 ve 45-64 yaş grubunda \%10 düzeyindedir (Marshall, 2009). Yine aynı araştırmaya göre internet kullanan Amerikalı yetişkinlerin \%47'si sosyal ağları ve \% 19'u Twitter veya benzer servisleri kullanmaktadır.

InSites Consulting 2010 yılında 14 den fazla ülkede 18 ve 55 yaş arası, 2,884 tüketici ile sosyal ağlar üzerine gerçekleştirdiği bir çevrimiçi araştırmaya göre katılımcıların \%90'1 en azından 1 sosyal ağ sitesini tanıyor, ve katılımciların \% 72'si en azından bir sosyal ağ sitesine üye. Ortalama olarak insanlar 195 civarında arkadaşa sahipler ve günde iki kez sosyal ağ sitelerini ziyaret ediyorlar (Tay, 2011).

\subsection{Sosyal Medya'nın Önemi}

Weber, (2009) kitabının önsüzünde sanal dokunun (web) her şeyi değiştirdiğgini ve değiştirmeye devam edeceğini belirterek, vurgulamaktadır. "Saydam bir içerik dünyası, çoğunlukla kullanıcılar tarafından meydana getirilmiş, geniş bantlı, birçok cihaz üzerinden ulaşılabilir, gelişmeye devam eden zengin bir medyadır. Sanal doku televizyon, basılı medya, radyo ve doğrudan posta gibi neredeyse bütün geleneksel medyayı kuşatmış durumdadır. Pazarlamayı diyaloglar dizini haline getirecektir. Şirketler bu diyaloğa katkı sağlamayı öğrenmek, halihazırdaki ve potansiyel müşterileriyle paylaşmak zorunda olacaktır".

Bilim adamları, pazarlamacılar, reklamcılar, politikacılar sosyal etkileşimlerin bir temsilcisi olarak, görüşlerinin propagandasını yapmak, sosyal ă̆ dinamiklerini harekete geçirmek, ağızdan ağıza pazarlama yapmak için çevrimiçi sosyal ağları yoğun olarak kullanmaktadırlar (Huberman, Romero, Wu, 2008:1). Alışveriş yaparken, planlama yaparken, bir şey öğrenirken ve iletişim kururken veya herhangi bir şey yaparken, sosyal ağ, faaliyetimizin birincil merkezi olacaktır. Hayatımızın tamamını işgal etmese bile, eski geleneksel medyanın sağladığ 1 , haber ve bilgi edinmek için, eğlenmek ve oyalanmak için hayatımızın ilk sırasında olacaktır (Weber, 2009:15).

Bir pazarlamacı için sosyal medya, tüketiciyi tanımanın en işlevsel yolu olabilir. Sosyal medya için unutulmaması gereken en önemli unsur da müşterilerin ve potansiyel müşterilerin her türlü bilgi alışverişinde bulunuyor olmasıdır. Zaten bu alt yapıyı kullanmadaki amaç da budur: Müşteriyi tanımak, onu ortamında yakalamak ve ona mesaj göndermekle uğraşmadan, onun gelip mesajı almasını sağlamak! Başka bir ifadeyle olta balıkçılığını bırakıp "ağ” kurmaktır. Bu nedenle tüketiciyi sıkacak; kızdıracak, mutsuz edecek herhangi bir tutumdan kaçınmak gerektiği aşikardır. Zaten bu, potansiyel tüketicilerin isteyerek var olduğu sosyal medya ortamında karşılaşmaması gereken eski usul bir sorundur.

Sosyal Medyayı kullanarak yapılan e-pazarlamayı diğer pazarlama araçlarından farklılaştıran en temel unsur; şüphesiz müşteri faktörüdür. Geçmişe nazaran; müşteriler daha bilinçli ve bilgi arayışında olan bireylerden oluşmaktadır. $\mathrm{Bu}$ tip müşteriler, ne istediğini ve ne elde etmek istediğini bilen, istek ve şikayetlerini rahatlıkla iletmekte herhangi bir kaygı görmeyen tüketicilerden oluşmaktadır. Bunun temel nedeni; dünya üzerinde yeni tüketim gruplarını 
oluşturan genç nüfusların günün teknolojik yatkınlığına sahip çocukları olmasıdır. Klasikleşen ve tüketici ilgisini yakalamaktan uzak web sitelerinin bir adım ötesinde duran sosyal medya ise; yükselen değer olarak iletişim araçları içerisinde yerini almış durumdadır. Diğger bir deyiş ile internetin var ettiği bu yeni mecra sayesinde "müşteriye değil, müşteri ile" konuşmak mümkün hale gelmiş bulunmaktadır.

\subsection{Sosyal Medya Kullanım Gerekçeleri}

Temel olarak sosyal medya profesyonel ve kişisel kullanım olarak iki amaçla kullanılmaktadır. Kişisel amaçla kullanım konusunda yapılan araştırmalardan, Brandtzaeg ve Heim'in 2007 yılında 1200 Sosyal A ğ Sitenin kullanıcılarıyla yaptıkları araştırma sonuçlarına göre; Araştırmaya katılanların \%31'i yeni ilişkiler kurmak amacıyla, \%21'i arkadaşları ve tanıdıkları ile iletişim kurmak amacıyla, \%14'ü sosyalleşme amacıyla, \%10'u çeşitli konularda bilgi edinmek amacıyla, \%6,5'i tartışmalara katılmak amacıyla sosyal ağları kullanmaktadırlar. Aynı araştırmada, Ücretsiz SMS göndermek, zaman öldürmek, içerik paylaşmak, amaçsız eğlence, profil arama, aile ile görüşme de sosyal ağları kullanma amaçlarından diğerleri olarak ortaya çıkmıştır.

Princeton Survey Research Associates International tarafindan 2011 yılında 18 yaş ve üstü, internet kullanıcısı 2277 Amerikalı ile telefonla yapılan araştırma sonuçlarına gore; çevrimiçi kullanıcıların üçte ikisi (\% 66) Facebook, Twitter, MySpace veya LinkedIn gibi sosyal medya platformlarını kullanmaktadırlar. Bu internet kullanıcıları, aile üyeleri, eski ve yeni arkadaşlar ile temas kurmanın sosyal medya araçlarını kullanmaya adapte olmalarının en önemli nedeni olduğunu söylemişlerdir. Sosyal medya kullanıcılarının yaklaşık üçte ikisi için mevcut arkadaşlarla ve aile üyeleriyle temas halinde olmak bu siteleri kullanmalarının başlica nedenidir. Kullanıcıların yarısı da teması kaybettikleri eski arkadaşları ile bağlantıya geçmenin bu teknolojileri kullanmalarının başlıca nedeni olduğunu belirtişlerdir. Daha az rol oynayan diğer nedenler de şu şekilde sıralanabilir. Kullanıcıların \%14'ü ortak hobi veya ilgi alanını paylaşmanın sosyal medya kullanmalarının önemli gerekçesi olduğunu vurgularken, \%9'u yeni arkadaşlıklar edinmenin aynı derecede önemli olduğunu belirtmişlerdir. Kamuoyuna mal olmuş kişilerin yorumlarını okumak \%5'I için, potansiyel romantik partnerler bulmak \%3’ü için en önemli gerekçe olarak görülmektedir (Smith, 2011).

2013 yılında Avrupa Birliği'ndeki İşletmelerle yapılan bir araştırmada; işletmelerin \%30'unun sosyal medyayı (sosyal ağlar, bloglar, içerik paylaşan siteler ve wikiler vb.) kullandığ görülmektedir. $\mathrm{Bu}$ işletmelerin yaklaşık dörtte üçü (\%73) olumlu bir imaj geliştirmek ve ürünlerini pazarlamak için sosyal medyayı kullanmaktadır. Sosyal ağlar işletmelerin favori sosyal medya formudur. İşletmelerin yarısı, özellikle konaklama sektöründe faaliyet gösteren işletmeler, müşterilerin görüşlerini, yorumlarını almak için veya müşterilerin sorularına cevap vermek için sosyal medyayı kullandıklarını belirtmişlerdir (Giannakouris ve Smihily, 2013).

\section{METODOLOJI}

\subsection{Verilerin Analizi Ve Bulgular}

Araştırmanın değerlendirilmesi sürecinde SPSS 16.0 paket programı kullanılmıştır. Analiz öncesinde veriler kodlanıp analize uygun hale getirilmiştir. Verilerin analizinde ilk olarak, her bir soru için elde edilen bulgulara yönelik yüzde ve frekans analizleri gerçekleştirilmiştir. Yüzde ve frekans analizlerinin yanı sıra, aralıklı ölçek tarzında oluşturulan 17 önermenin, konuya ilişkin ifade ettikleri boyutları gruplandırabilmek için faktör analizi uygulanmıştır. Söz konusu önermelere faktör analizinin uygulanmasının nedeni, bir faktörü oluşturan değişken setlerini belirlemek ve aynı boyutu ölçen değişkenleri gruplandırabilmektir. Bilindiği gibi faktör analizi, değişkenler arasındaki karşılıklı ilişkileri inceleyerek, değişkenlerin daha anlamlı ve özet bir şekilde sunulmasını sağlamaktadır (Bayram, 
2004:131). Faktör analizinde amaç; değişken sayısını azaltmak ve değişkenler arası ilişkilerdeki yapıyı ortaya çıkarmak, değişkenleri sınıflandırmaktır (Kalaycı, 2006:321).

Gruplar arasındaki ilişkilerin incelendiği veriler için parametrik olmayan analiz tekniklerinden "Mann-Whitney U Testi” ve "Kruskal-Wallis Testi”nin kullanılması uygun bulunmuştur. Öncelikle demografik özelliklerde yer alan bağımsız değişkenlerden cinsiyetin faktör bileşenleri üzerindeki etkisi, normal dağılım varsayımı sağlanmadığı için parametrik olmayan, bağımsız iki grup arasındaki farklılıkların testi Mann-Whitney $U$ ile $p<0,05$ anlamlılık düzeyinde araştırılmıştır. Öğrencilerin devam ettikleri sınıfların faktör bileşenleri üzerinde etkisi olup olmadığı ise, benzer şekilde normal dağılım varsayımı sağlanmadığı için gruplar arası tek yönlü varyans analizinin parametrik olmayan karşılığı Kruskal-Wallis testi ile $(\mathrm{p}<0,05)$ anlamlılık düzeyinde araştırılmıştır.

Araştırma kapsamında değişkenler arasındaki ilişkileri araştırmak üzere oluşturulan iki ana hipotez aşağıdaki gibidir:

$\boldsymbol{H}_{0}$ : Öğrencilerin sosyal medya kullanım amaçlarını ifade eden faktörler bakımından kadın ve erkek ögrencilerin ortalamaları arasında fark yoktur.

$\boldsymbol{H}_{1}:$ Öğrencilerin sosyal medya kullanım amaçlarını ifade eden faktörler bakımından kadın ve erkek ögrencilerin ortalamaları arasında fark vardır.

$\boldsymbol{H}_{0}$ : Öğrencilerin sosyal medya kullanım amaçlarını ifade eden faktörler bakımından farklı sınıflarda okuyan ögrencilerin ortalamaları arasında fark yoktur.

$\mathrm{H}_{2}:$ Öğrencilerin sosyal medya kullanım amaçlarını ifade eden faktörler bakımından farklı sinıflarda okuyan ögrencilerin ortalamaları arasında fark vardır.

\subsection{Katılımcıların Demografik Özelliklerine Yönelik Araștırma Bulguları}

Yapılan istatistiksel veri analizi ile ankete katılan 389 örneklemin demografik özelliklerini gösteren tablo aşağıda verilmiştir.

Tablo 1. Araştırmaya Katılan Öğrencilerim Demografik Özellikleri

\begin{tabular}{|l|r|r|l|r|r|}
\hline CINSIYYET & $\mathbf{n}$ & $\mathbf{9}$ & ORTALAMA AYLIK & $\mathbf{n}$ & \% \\
Erkek & 184 & 47,3 & GELIR & 148 & 38,1 \\
Kadın & 200 & 51,4 & 500 TL ve alt1 & 142 & 36,6 \\
Kayıp veri & 5 & 1,3 & $501-1000 \mathrm{TL}$ & 11 & 2,6 \\
& & & $1001-1500 \mathrm{TL}$ & 4 & 1,1 \\
Toplam & $\mathbf{3 8 9}$ & $\mathbf{1 0 0 , 0}$ & 1501 TL ve üstü & 84 & 21,6 \\
\hline SINIF & $\mathbf{n}$ & $\mathbf{9}$ & Kayıp veri & $\mathbf{3 8 9}$ & $\mathbf{1 0 0 , 0}$ \\
1 & 45 & 11,6 & Toplam & & \\
2 & 69 & 17,7 & & & \\
3 & 152 & 39,1 & & & \\
4 & 83 & 21,3 & & & \\
Kayıp veri & 40 & 10,3 & & & \\
Toplam & $\mathbf{3 8 9}$ & $\mathbf{1 0 0 , 0}$ & & & \\
\hline
\end{tabular}


Tablo 1'de de görüldüğü gibi, araştırmaya katılan öğrencilerin \%51,4’ü (200 kişi) kadın, \%47,3'ü (184 kişi) ise erkeklerden oluşmaktadır.

Araştırmaya katılan öğrencilerin devam etmekte oldukları sınıf kategorilerine göre dağılımları dikkate alındığında, büyük bir çoğunluğunun $(\% 39,1) 3$. sınıf öğrencilerinden oluştuğu görülmektedir. Katılımcıların \%21,3'ü 4. sinıf, \%17,7'si 2. Sinıf ve \% 11,6's1 1. sinıf öğrencileridir.

Ankete katılan öğrencilerin aylık ortalama gelir düzeyleri ile ilgili yöneltilen açık uçlu soruya verilen yanıtlara göre; katılımcıların \%38,1'i (148 kişi) aylık ortalama gelirlerinin " 500 TL ve altı" olduğunu ifade etmişlerdir. Buna çok yakın bir oranla katılımcıların \%36,6'sının ise aylık ortalama gelirleri 501-1000 TL arasındadır. Katılımciların \%2,6's1 "1001-1500 TL" arası, \%1,1’i “1501 TL ve üzeri” aylık ortalama gelire sahiptir.

\subsection{Katılımcıların İnternet ve Sosyal Medya Kullanımlarına İlişskin Araştırma Bulguları}

Anketi yanıtlayan 389 öğrencinin \%99,7 (388 kişi) gibi büyük bir oranı internet kullanıcısı olduklarını belirtmişlerdir. Katılımcıların \%98,7 (384 kişi) internet kullanımları sırasında sosyal paylaşım siteleri ve blogları ziyaret ettiklerini ifade etmişlerdir. Örnekleme dahil edilen ögrencilerin \%73,3'ü interneti her gün ziyaret ettiklerini belirtirken, $\% 20,1$ 'i haftada 2-3 gün, \%2,8'i hafta bir gün ve \%2,1'si de ayda 1-2 gün internete girdiklerini ifade etmişlerdir. "Kendinize ait bir blogunuz var mi?" sorusuna verilen yanıtlar analiz edildiğinde ise öğrencilerin \%78,2'inin "hayır” şeklinde yanıt verdikleri görülmektedir.

Hazırlanan anket doğrultusunda, araştırmaya katılan öğrencilerin sosyal medya sitelerinden en sık kullandıkları 5 tanesini önem sırasına göre sıralamaları istenmiştir. Bu soruda öğrencilerin tercihleri frekans sıklıkları bakımından analiz edilmiştir. Analiz sonucuna göre öğrencilerin en s1k kullandıkları sosyal medya sitesi \%91,6 oranı ile "facebook"”tur. Öğrencilerin sosyal medya siteleri içerisinde ikinci tercihleri ise $\% 83$ oranı ile "youtube" dur. Diğer tercihleri ise şu şekilde sıralanmaktadır; 3 . tercih $(\% 65,8)$ "msn”, 4. tercih $(\% 49,6)$ "wikipedia” ve 5 . tercih (\%33) "ekşi sözlük”.

Tablo 2. Katılımcıların Sosyal Medya Kullanımında Ürün ve Satın Alma Deneyimlerine İlişkin Araştırma Bulguları

\begin{tabular}{|c|c|c|c|c|c|c|c|c|c|c|c|c|c|}
\hline & \multicolumn{2}{|c|}{$\ddot{Z}$} & \multicolumn{2}{|c|}{ 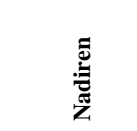 } & \multicolumn{2}{|c|}{ 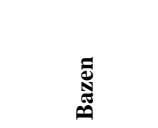 } & \multicolumn{2}{|c|}{$\frac{4}{\bar{n}}$} & \multicolumn{2}{|c|}{ 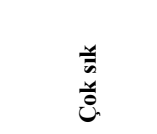 } & \multicolumn{2}{|c|}{$\sum_{\substack{1 \\
0}}$} & \multirow[t]{2}{*}{$\begin{array}{c}\text { Medyan } \\
\text { Değeri }\end{array}$} \\
\hline & $\mathrm{n}$ & $\%$ & $\mathbf{n}$ & $\%$ & $\mathbf{n}$ & $\%$ & $\mathrm{n}$ & $\%$ & $\mathrm{n}$ & $\%$ & $\mathrm{n}$ & $\%$ & \\
\hline $\begin{array}{l}\text { Arkadaşlarınız } \\
\text { tarafindan size ürün } \\
\text { yorumları içeren } \\
\text { mesaj ve görüntüler } \\
\text { gönderilir mi? }\end{array}$ & 53 & 13,6 & 61 & 15,7 & 129 & 33,2 & 78 & 20,1 & 60 & 15,4 & 389 & 100 & 2,00 \\
\hline $\begin{array}{l}\text { Siz arkadaşlarınıza } \\
\text { ürün yorumları içeren } \\
\text { mesaj ve görüntüler } \\
\text { gönderir misiniz? }\end{array}$ & 183 & 47 & 58 & 14,9 & 63 & 16,2 & 53 & 13,6 & 24 & 6,2 & 389 & 100 & 1,00 \\
\hline $\begin{array}{l}\text { Internet ortamindaki } \\
\text { ürün yorumlarını } \\
\text { okur musunuz? }\end{array}$ & 44 & 11,3 & 69 & 17,7 & 109 & 28 & 98 & 25,2 & 62 & 15,9 & 389 & 100 & 2,00 \\
\hline $\begin{array}{l}\text { Bir ürün } \quad \text { satın } \\
\text { almadan önce o ürünü } \\
\text { internette araştırır } \\
\text { mısınız? }\end{array}$ & 18 & 4,6 & 24 & 6,2 & 68 & 17,5 & 121 & 31,1 & 151 & 38,8 & 389 & 100 & 3,00 \\
\hline
\end{tabular}


Araştırmaya katılan öğrencilerin sosyal medya kullanımında ürün yorumları ve satın alma araştırmaları deneyimlerini belirlemeye yönelik hazırlanan dört soru "0- Hiç, 1-Nadiren, 2Bazen, 3-S1k ve 4-Çok sik" şeklinde oluşturulmuş beşli bir derecelendirme ölçeği kullanılmıştır. Söz konusu kriterlere verilen yanıtların medyan değerleri Tablo 2'de verilmiştir. "Arkadaşlarınız tarafından size ürün yorumları içeren mesaj ve görüntüler gönderilir mi?" sorusuna verilen yanıtların medyan değeri 2,00'dır. Bu değer ankette yer alan " 2 = bazen" değerine karşılık gelmektedir. Bu sorunun analizinden elde edilen bulgular, katılımcıların büyük bir oranının $(\% 33,2)$ arkadaşlarından gelen ürün yorumları içeren mesaj ve görüntülere bazı zamanlarda (bazen) maruz kaldıklarının göstergesidir. "Siz arkadaşlarınıza ürün yorumları içeren mesaj ve görüntüler gönderir misiniz?" sorusuna yönelik yanıtların medyan değeri 1,00'dır. Bu değer de ankette yer alan "1 = nadiren" değerine karşılık gelmektedir. Sonuçlardan da görüldüğü üzere, katılımcıların yüksek bir oranı (\%47) arkadaşlarına ürün yorumları içeren mesaj ve görüntüleri nadiren göndermektedirler. "Internet ortamındaki ürün yorumlarını okur musunuz?" sorusuna verilen cevapların medyan değeri ise 2,00'dır. Bu değer de yine ankette yer alan " 2 = bazen" değerini ifade etmektedir. Anketi yanıtlayan öğrenciler internet ortamında yer alan ürün yorumlarını bazen dikkate almaktadırlar. "Bir ürün satın almadan önce o ürünü internette araştırır misınız?" sorusuna verilen yanıtların medyan değeri 3,00'dır. Bu değer ankette yer alan "3 = sık" değerine karşılık gelmektedir. Bu sorunun analizinden elde edilen bulgular, katılımcıların bir ürünü satın almadan önce sıklıkla internetten araştırma yaptıklarını göstermektedir.

\section{4. Öğrencilerin Sosyal Medya Kullanım Amaçlarını Belirlemeye Yönelik Faktör Analizi}

Araştırmaya katılan öğrencilerin sosyal medya sitelerini kullanım amaçlarının farklı boyutlarını ortaya koyabilmek için, araştırma kapsamında kullanılan ölçekte yer alan önermeler faktör analizine tabi tutulmuş ve analiz sonucuna göre yapı geçerliliği sağlanmış maddeler son ölçekte yer almıştır.

Faktör analizi ile araştırmaya katılan öğrencilerin sosyal medyayı kullanım nedenlerinin belirlenmesi amaçlanmıştır. Faktör analizinin sonucunun yorumlanabilir olmasına KMO ve Bartlett Testi sonuçları dikkate alınarak karar verilmiştir. Ölçeğin KMO değeri 0,803 ve Bartlett küresellik testi sonucu 1737,296 bulunmuştur KMO değerleri faktör analizinin iyi olup olmadığı hakkında bilgi vermektedir. KMO ölçütü 1'e ne kadar yakınsa verilerin faktör analizi için o kadar uygun olduğunu göstermektedir. KMO değerleri için; " $0,90=$ mükemmel”, " $0,80=$ çok iyi", " $0,70=$ iyi", " $0,60=$ orta", " $0,50=$ zayif" ve " 0,50 'nin alt1 =kabul edilemez" şeklinde bir sınıflandırma yapılmaktadır (Kalaycı, 2006:322). Daha sonra, çalışmanın faktör analizinde dik eksen döndürme tekniği tercih edilmiştir. Varimax dik eksen döndürme tekniği kullanılarak yapılan faktör analizine ilk aşamada, ölçekte yer alan 17 madde ile başlanmıştır. Daha sonra her bir faktör grubunda yer alan önermelerin Cronbach Alpha iç tutarlılık katsayıları hesaplanmış ve güvenilirlik katsayıları 0,60'dan küçük olan beş madde ölçekten çıkarılmıştır. Ölçek son hali ile yeniden faktör analizine tabi tutulmuş ve analizde temel alınan bu 12 madde için özdeğeri "1"in üzerinde olan dört bileșen olduğu belirlenmiştir. Bunlar sırasıyla; "sosyal paylaşımlar", "ürün ve marka seçimi”, "iletişim” ve "bilgiye erişim"dir. Ölçekte faktör yüklerinin 0,568-0,857 arasında değiştiği görülmektedir. Belirlenen dört faktörün varyansa yaptıkları toplam katkı ise \%71,115'tir.

Ölçeğin güvenilirliği için hesaplanan alt boyutların Cronbach Alfa katsayıları, "sosyal paylaşımlar" için 0,877 ; "ürün ve marka seçimi" için 0,805 ; "iletişim" 0,618 ve "bilgiye erişim" için ise 0,609 değerlerinde bulunmuştur. Ölçeğin bütünü için elde edilen Cronbach Alfa değeri ise 0,818 'dir. 
Bu sonuçlar, maddelerin faktör analizi için uygun olduğunu, yapı geçerliğinin sağlandığını ve güvenilir bulunduğunu göstermektedir. Varyansa katılma yüzdesi birden büyük olan dört faktör toplam varyansın \% 71,115'nını açıklama yeteneğine sahiptir. "Sosyal paylaşımlar" en yüksek açıklayıcılığa sahip faktör $(\% 24,532)$ olarak karşımıza çıkmaktadır.

Tablo 3. Faktör Analizi Sonucu

\begin{tabular}{|c|c|c|c|c|c|c|}
\hline \multirow[b]{2}{*}{ Madde } & \multicolumn{4}{|c|}{$\begin{array}{l}\text { Faktör Yük Değerleri } \\
\end{array}$} & \multirow[b]{2}{*}{ Özdeğer } & \multirow{2}{*}{$\begin{array}{l}\text { Varyans } \\
\text { Açıklama } \\
\text { Oranı (\%) }\end{array}$} \\
\hline & $\begin{array}{c}\text { Sosyal } \\
\text { Paylaşımlar }\end{array}$ & $\begin{array}{l}\text { Ürün ve } \\
\text { Marka } \\
\text { Seçimi }\end{array}$ & İletişim & $\begin{array}{l}\text { Bilgiye } \\
\text { Erişim }\end{array}$ & & \\
\hline S.37 & ,888 & & & & \multirow{4}{*}{2,944} & \multirow{4}{*}{24,532} \\
\hline S.38 & ,868 & & & & & \\
\hline S.36 & ,863 & & & & & \\
\hline S.39 & ,679 & & & & & \\
\hline S.48 & &, 884 & & & \multirow[b]{3}{*}{2,246} & \multirow[b]{3}{*}{18,720} \\
\hline $\mathrm{S} .47$ & & ,857 & & & & \\
\hline S.49 & & ,785 & & & & \\
\hline S.42 & & & ,745 & & \multirow[b]{3}{*}{1,842} & \multirow[b]{3}{*}{15,351} \\
\hline S.41 & & & ,720 & & & \\
\hline S.40 & & & ,663 & & & \\
\hline S.35 & & & & ,811 & \multirow[b]{2}{*}{1,502} & \multirow[b]{2}{*}{12,513} \\
\hline $\mathrm{S} .43$ & & & & ,750 & & \\
\hline \multicolumn{7}{|c|}{$\begin{array}{l}\text { KMO=0,803 } \\
\text { Bartlett Küresellik Testi=1737,296 } \\
\text { Sig. }=0,000 \\
\text { df }=66\end{array}$} \\
\hline
\end{tabular}

"Sosyal paylaşımlar" faktörü altında yer alan önermeler incelendiğinde, öğrencilerin sosyal medya sitelerini öncelikli kullanım amacının müzik, video ve fotoğraf paylaşımı yapmak ve anlık durum iletimi fonksiyonlarını kullanmak olduğu görülmektedir. "Marka ve ürün seçimi" olarak adlandırılan ikinci faktör grubunda yer alan önermeler incelendiğinde, öğrencilerin ürün ve marka satın alma kararını vermeden önce sosyal medya sitelerindeki yorum ve tavsiyeleri dikkate aldıkları anlaşılmaktadır. Satın alma kararı verilmeden önce başvurulan en önemli bilgi kaynaklarından biri olan internet ve sosyal medya ortamlarında kullanıcıların yorumları öğrenciler tarafından dikkate alınmakta ve kimi zamanlarda sosyal medya siteleri bu amaçla özellikle kullanılmaktadır. "İletişim" faktörü de öğrencilerin sosyal medya kullanım amaçlarından bir diğeridir. Bu faktör altında yer alan önermeler incelendiğinde, sosyal medya sitelerinin sosyalleşmek, arkadaşlar veya diğer sosyal medya kullanıcıları ile iletişime geçmek, kendini ifade etmek, rahatlamak, fikir alışverişinde bulunmak vb. gibi pek çok fonksiyona sahip olduğu açıkça görülmektedir. Araştırmaya katılan öğrencilerin sosyal medya sitelerini kullanmalarının bir diğer amacı da "bilgiye erişim" faktörü olarak belirlenmiştir. Gerek akademik gerekse güncel bilgi kaynağı olması açısından pek çok sosyal medya sitesi öğrencilerin bu konudaki ihtiyaçlarını karşılamakta, özellikle öğrenim süresi boyunca akademik ve entelektüel gelişimlerine katkı sağlamaktadır. 


\section{5. Öğrencilerin Sosyal Medya Kullanım Amaçlarını İfade Eden Faktörlerin} Cinsiyete Göre Farklılaşıp Farklaşmadığına Yönelik Gerçekleştirilen Mann-Whitney U Testi ve Sonuçları

Öğrencilerin sosyal medya kullanım amaçlarını ifade eden faktörlerin cinsiyetlerine göre farklılaşıp farklılaşmadığını test etmeye yönelik gerçekleştirilen Mann-Whitney U Testi sonuçlarını gösteren tablo aşağıda verilmiştir.

Tablo 4. Öğrencilerin Sosyal Medya Kullanım Amaçlarını İfade Eden Faktörler ve Cinsiyetlerine Yönelik Mann-Whitney U Testi Sonuçları

\begin{tabular}{|c|c|c|c|c|c|}
\hline Bağımlı Değişken & Bağımsız Değişken & $\mathbf{N}$ & $\begin{array}{c}\mathrm{Z} \\
\text { değeri }\end{array}$ & $\begin{array}{l}\text { P değeri } \\
\text { (Astmp. } \\
\text { Sig.) } \\
\end{array}$ & Açıklama \\
\hline \multirow{3}{*}{$\begin{array}{c}\text { SOSYAL } \\
\text { PAYLAŞIMLAR }\end{array}$} & Cinsiyet & 350 & \multirow{3}{*}{,- 999} & \multirow{3}{*}{,318 } & \multirow{3}{*}{$\begin{array}{l}\text { Katılımcıların sosyal medya kullanım } \\
\text { amaçlarını ifade eden "sosyal } \\
\text { paylaşımlar" faktörü cinsiyete göre } \\
\text { farklılaşmamaktadır. }\end{array}$} \\
\hline & Kadın & 181 & & & \\
\hline & Erkek & 169 & & & \\
\hline \multirow{3}{*}{$\begin{array}{c}\text { ÜRÜN VE } \\
\text { MARKA SEÇIMI }\end{array}$} & Cinsiyet & 350 & \multirow{3}{*}{$-1,373$} & \multirow{3}{*}{,170 } & \multirow{3}{*}{$\begin{array}{l}\text { Katılımcıların sosyal medya kullanım } \\
\text { amaçlarını ifade eden “ürün ve marka } \\
\text { seçimi” faktörü cinsiyete göre } \\
\text { farklılaşmamaktadır. }\end{array}$} \\
\hline & Kadın & 181 & & & \\
\hline & Erkek & 169 & & & \\
\hline \multirow{3}{*}{ İLETİŞİM } & Cinsiyet & 350 & \multirow{3}{*}{,- 557} & \multirow{3}{*}{,578 } & \multirow{3}{*}{$\begin{array}{l}\text { Katılımcıların sosyal medya kullanım } \\
\text { amaçlarını ifade eden "iletişim" } \\
\text { faktörü cinsiyete göre } \\
\text { farklılașmamaktadır. }\end{array}$} \\
\hline & Kadın & 181 & & & \\
\hline & Erkek & 169 & & & \\
\hline \multirow{3}{*}{$\begin{array}{l}\text { BİLGIYYE } \\
\text { ERİşìM }\end{array}$} & Cinsiyet & 350 & \multirow{3}{*}{$-2,854$} & \multirow{3}{*}{, $004 *$} & \multirow{3}{*}{$\begin{array}{l}\text { Katılımcıların sosyal medya kullanım } \\
\text { amaçlarını ifade eden "bilgiye erişim" } \\
\text { faktörü cinsiyete göre } \\
\text { farklılaşmaktadır. }\end{array}$} \\
\hline & Kadın & 181 & & & \\
\hline & Erkek & 169 & & & \\
\hline
\end{tabular}

$\mathrm{p}>0.05$ anlamsiz

$\mathrm{p}<0.05$ anlaml1*

güvenilirlik: \% 95

Gerçekleştirilen Mann-Whitney U Testi sonucuna göre, öğrencilerin sosyal medya kullanım amaçları çerçevesinde "bilgiye erişim" düzeylerinde cinsiyetlerine göre \%5 anlamlılık düzeyinde istatistiksel olarak anlamlı bir farklılık olduğu belirlenmiştir. Kadınların bilgiye erişim düzeylerine ait ortalama değerin $(190,41)$ erkek katılımcıların bilgiye erişim düzeyi ortalama değerinden $(159,53)$ daha yüksek olduğu görülmektedir.

\section{6. Öğrencilerin Sosyal Medya Kullanım Amaçlarını İfade Eden Faktörlerin Sınıflarına Göre Farklılaşıp Farklılaşmadığına Yönelik Gerçekleştirilen Kruskal-Wallis Testi ve Sonuçları}

Sosyal medya kullanım amaçlarını ifade eden faktörlerin öğrencilerin devam ettikleri sınıflara göre farklılaşıp farklılaşmadığını belirlemek üzere gerçekleştirilen Kruskal-Wallis testi sonucu elde edilen bulgular tablo 5 'te verilmiştir.

Gerçekleştirilen Kruskal-Wallis Testi sonucuna göre, öğrencilerin sosyal medya kullanım amaçlarını ifade eden faktörlerden hiçbirinin devam ettikleri sınıflara göre farklılaşmadığı ortaya konulmuştur. Bu durumda, ilgili değişkenler için oluşturulan " $\mathrm{H}_{2} / \mathrm{H}_{0}$ Hipotezi" nde alternatif hipotez reddedilmiş, sıfır hipotezi ise kabul edilmiştir. 
Tablo 5. Öğrencilerin Sosyal Medya Kullanım Amaçlarını İfade Eden Faktörler ve Sınıf Değişkenine Yönelik Kruskal-Wallis Testi Sonuçları

\begin{tabular}{|c|c|c|c|c|c|c|}
\hline Bağımlı Değişken & Bağımsız Değișken & $\mathbf{N}$ & $\chi^{2}$ & sd & Sig. & Açıklama \\
\hline \multirow{5}{*}{$\begin{array}{c}\text { SOSYAL } \\
\text { PAYLAŞIMLAR }\end{array}$} & Sinıf & 319 & \multirow{5}{*}{8,327} & \multirow{5}{*}{4} & \multirow{5}{*}{,080 } & \multirow{5}{*}{$\begin{array}{l}\text { Katılımcıların sosyal medya } \\
\text { kullanım amaçlarını ifade eden } \\
\text { "sosyal paylaşımlar" faktörü } \\
\text { devam ettikleri sınıflara göre } \\
\text { farklılaşmamaktadır. }\end{array}$} \\
\hline & 1. Sinif & 43 & & & & \\
\hline & 2. Sinif & 61 & & & & \\
\hline & 3. Sinıf & 135 & & & & \\
\hline & 4. Sinif & 80 & & & & \\
\hline \multirow{5}{*}{$\begin{array}{c}\text { ÜRÜN VE MARKA } \\
\text { SEÇIMİ }\end{array}$} & Sinıf & 319 & \multirow{5}{*}{3,078} & \multirow{5}{*}{4} & \multirow{5}{*}{,545 } & \multirow{5}{*}{$\begin{array}{l}\text { Katılımcıların sosyal medya } \\
\text { kullanım amaçlarını ifade eden } \\
\text { "ürün ve marka seçimi” faktörü } \\
\text { devam ettikleri sınıflara göre } \\
\text { farklılaşmamaktadır. }\end{array}$} \\
\hline & 1. Sinif & 43 & & & & \\
\hline & 2. Sinif & 61 & & & & \\
\hline & 3. Sinıf & 135 & & & & \\
\hline & 4. Sinıf & 80 & & & & \\
\hline \multirow{5}{*}{ İLETİ̧̧ìM } & Sinıf & 319 & \multirow{5}{*}{5,446} & \multirow{5}{*}{4} & \multirow{5}{*}{,245 } & \multirow{5}{*}{$\begin{array}{l}\text { Katılımcıların sosyal medya } \\
\text { kullanım amaçlarını ifade eden } \\
\text { "iletişim" faktörü devam ettikleri } \\
\text { sınıflara göre farklılaşmamaktadır. }\end{array}$} \\
\hline & 1. Sinif & 43 & & & & \\
\hline & 2. Sinif & 61 & & & & \\
\hline & 3. Sinif & 135 & & & & \\
\hline & 4. Sinıf & 80 & & & & \\
\hline \multirow{5}{*}{ BİLGIYE ERİŞIM } & Sinıf & 319 & \multirow{5}{*}{6,042} & \multirow{5}{*}{4} & \multirow{5}{*}{ 196 } & \multirow{5}{*}{$\begin{array}{l}\text { Katılımcıların sosyal medya } \\
\text { kullanım amaçlarını ifade eden } \\
\text { "bilgiye erişim" faktörü devam } \\
\text { ettikleri sınıflara göre } \\
\text { farklılaşmamaktadır. }\end{array}$} \\
\hline & 1. Sinif & 43 & & & & \\
\hline & 2. Sinif & 61 & & & & \\
\hline & 3. Sinif & 135 & & & & \\
\hline & 4. Sinif & 80 & & & & \\
\hline
\end{tabular}

$\mathrm{p}>0.05$ anlamsiz

$\mathrm{p}<0.05$ anlamlı*

güvenilirlik: \% 95

\section{Sonuç ve Öneriler}

Web 2.0 sayesinde internet üzerinden sağlanan iletişimin tek taraflı monologdan kurtularak, karşılıklı iletişim ve etkileşime olanak veren diyaloğa ve çoklu iletişime (multilogue) geçilmesi ile birlikte sosyal ağlar ve sosyal medya günlük yaşantımızın bir parçası haline gelmiş bulunmaktadır. Yeni teknoloji ve yazılımlar ile birlikte sosyal medya araçları gün geçtikçe çeşitlenmekte ve gelişmektedir. Günümüzde internet erişimi olan ve internetten yararlanan hemen hemen herkes sosyal medya araçlarını da kullanmakta, mesaj, fotoğraf, müzik, sesli ve hareketli görüntü göndererek ve/ veya kabul ederek, tanıdıkları veya tanımadıkları kişi, özel şirket, devlet kuruluşu, sivil toplum kuruluşu vb. kişi ve kurumlarla karşılıklı iletişim ve etkileşim içerisine girmektedir.

Günümüzde, sosyal medya araçları yoluyla paylaşılan görüş ve öneriler ile yapılan yorumlar, insanlar tarafindan klasik veya yeni medya araçları ile yapılan reklamlardan daha inandırıcı bulunmaktadır. Ayrıca paylaşılan görüş, öneri ve yorumlar büyük bir hızla yaygınlaşmakta, aranıldığında kolayca bulunabilecek biçimde kalıcı olmaktadır. Araştırma sonuçlarında da ortaya konulduğu gibi, internete ulaşım imkanı bulunan insanların büyük kısmı, artık alışveriş öncesi internet ortamında araştırma yapmakta, satın almak istedikleri ürün veya hizmet hakkındaki eleştirileri, önerileri dikkate almaktadır.

$\mathrm{Bu}$ nedenlerle, günümüzde sosyal medya, sadece kişi ve grupların kullandığı değil, aynı zamanda şirketlerin ve kurumların en önemli pazarlama aracı haline gelmiş bulunmaktadır. Sosyal medya araçlarını etkin ve verimli bir şekilde kullanabilen, güncel gelişmeleri takip edebilen, kişiler, şirketler, sivil toplum kuruluşları, devlet kuruluşları vs. hedeflerine ulaşma yolunda avantaj sağlamakta, daha rekabetçi olabilmektedirler. 


\section{REFERENCES}

- Bayram, N. (2004). Sosyal Bilimlerde SPSS ile Veri Analizi. Birinci Basım. İstanbul: Ezgi Kitabevi.

- Evans, D. (2008). Social Media Marketing: An Hour a Day. Indiana: Wiley Publishing.

- Giannakouris, K. ve Smihily, M. (2013). Businesses raise their internet profile by using social media. Statistics in focus 28/2013; European Commission - Eurostat. ISSN:2314-9647 Catalogue number:KS-SF-13-028-EN-N

- Kalaycı, Ş. (2006). "Faktör Analizi”, SPSS Uygulamalı Çok Değişkenli İstatistik Teknikleri. Ed.:Şeref Kalaycı. İkinci Basım. Ankara: Asil Yayın.

- Weber, L. (2009). Marketing To The Social Web: How Digital Customer Communities Build Your Business. New Jersey: John Wiley \& Sons.

- Boyd, D. M. ve Ellison, N. B. (2007, December 17). Social Network Sites: Definition, History, And Scholarship. Journal Of Computer-Mediated Communication,. Journal of Computer-Mediated Communication , pp. 210-230.

- Brandtzaeg, P. B. ve Heim J. (2007). Why People Use Social Networking Sites. Citizen Media Social Change EC IST FP6. İndirilme tarihi: 20 Mart 2014 URL: http://www.slideshare.net/ PetterB/why-people-use-social-networkign-sites\#

- dijitalajanslar.com (2014). İnternet ve Sosyal Medya Kullanıcı İstatistikleri 2014. İndirilme tarihi: 19 Şubat 2014 URL:http://www.dijitalajanslar.com/internet-vesosyal-medya-kullanici-istatistikleri-2014/

- Granfield, M. (2011, March 27). Social Media Marketing for the Tourism Industry. İndirilme tarihi: 20 Nisan 2011, URL: Slideshare.net: http://www.slideshare.net/mattgranfield/social-media-marketing-for-the-tourismindustry

- Lips, K. (2011). Social Media And Tourism 2.0. Kisky Netmedia: İndirilme tarihi: 20 Nisan 2011, URL:www.kisky.co.uk

- Nielsen Company (2009). Global Advertising: Consumers Trust Real Friends and Virtual Strangers the Most. İndirilme tarihi: 17 Ekim 2011, URL: http://blog.nielsen.com/nielsenwire/ consumer/global-advertising-consumers-trustreal-friends-and-virtual-strangers-the-most/

- Robles, P. (2010). Consumers don't trust advertising, is social media part of the solution?

- İndirilme tarihi: 14 Nisan 2011, URL: http://econsultancy.com/uk/blog/5927consumers-don-t-trust-advertising-is-social-media-part-of-the-solution

- Rothamel, D. (2007). How Your Business Can Benefit From Social Media Right Now. İndirilme tarihi: 10 Nisan 2010, URL: http://agentgenius.com/real-estate-technologynew-media/how-your-business-can-benefit-from-social-media-right-now/

- Smith, A. (2011). Why Americans use social media. November 15, 201. Pew Research Internet Project. İndirilme tarihi: 28 Mart 2014 URL: http://www.pewinternet.org/

- 2011/11/15/methodology-48/

- Tay, R. (2011). Impact of Social Media on Society. İndirilme tarihi: 17 Ekim 2011, URL: http://ezinearticles.com/?Impact-of-Social-Media-on-Society\&id=5378885

- Tourism Queensland. (2011). Social Media For Tourism Tutorial 28. Tourism Queensland Indirilme tarihi: 20 Nisan 2011, 
URL:http://www.tourismtasmania.com.au/_data/assets/ pdf_file/0004/37489/Tutorial_28_-_Social_Media_For_Tourism.pdf

- We are social (2014). Global Digital Statistics 2014. We Are Social's Snapshot Of Key Digital Indicators. 2014 Edition. Indirilme tarihi: 19 Şubat 2014 URL: wearesocial.sg•@wearesocialsg

- Wikipedia. (2011). Social Media. Wikipedia.Org. İndirilme tarihi: 20 Nisan 2011, URL: http://En.Wikipedia.Org/Wiki/Social_Media 